\title{
Morphometrical and histochemical foundation of pancreas and ductal system in white-eared bulbul (Pycnonotus leucotis)
}

\author{
S.S.A. Al-Khakani" I.M.J. Zabiba, K.H. Al-zubaidi and E.A.H. Al-alwany \\ Department of Anatomy and Histology, College of Veterinary Medicine, Al-Qasim Green University, Iraq \\ drsalimsailh2@gmial.com
}

(Received May 2, 2018; Accepted September 8, 2018)

\begin{abstract}
The present study was designed to find the macroscopic, microscopic and histocamical properties in pancreas of whiteeared bulbul (pycnonotus leucotis) and ductal system, ten healthy adult birds were transferred to the veterinary anatomy laboratory in Al-Qasim green university. Macroscopic study revealed that the pancreas was white in color, formed from two lobes, the ventral lobe navicular in shape while the dorsal lobe was very thin like triangular in appearance but longer than the ventral lobe. The two lobes were not occupy the space between the descending and ascending limbs of duodenum, the mean weight of birds and whole pancreas was $(27.6 \pm 3.04),(0.07 \pm 0.022) \mathrm{gm}$ respectively, the mean weight of dorsal and ventral lobes was $(0.034 \pm 0.005),(0.036 \pm 0.0054)$ gm respectively and the mean length of dorsal and ventral lobe was $(1.3 \pm 0.05)$, $(0.88 \pm 0.03) \mathrm{cm}$ respectively. The pancreas was a small organs in white-eared bulbul. The result of microscopic study that the pancreas in white-eared bulbul similar to other birds and covered by a thin C.T capsule with mesothelium cells. The pancreas parenchyma was consisted of exocrine and endocrine portions, the Langerhans island appeared in dorsal lobe in all histological sections which composed of different shapes and sizes. The intercalated ducts of ductal system lined by simple to low cuboidal cells then the epithelia changed to simple cuboidal in interlobular duct and become columnar in larger ducts. The main excretory ducts composed of three histological layers mucosa, muscularis and adventitia.
\end{abstract}

Keywords: white -eared, pancreas, ductal system, bulbul Available online at http://www.vetmedmosul.com

\section{دراسة شكلية قياسية وكيمياء نسجية للبنكرياس وقنواتها الافرازية في طير البلبل ذي الاذن البيضاء سالم صالح علي الخيكاني، عصام عحم جابر زبيبه، كاظم عبد زيد الزبيدي، اخلاص عبد حمزه العلواني فرع التثريح و الأنسجة، كلية الطب البيطري، جامعة القاسم الخضراء، العراق}



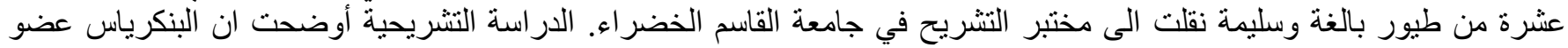

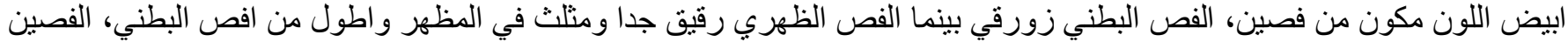

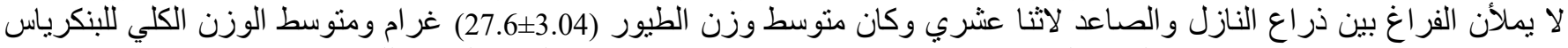

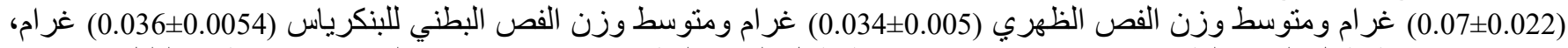

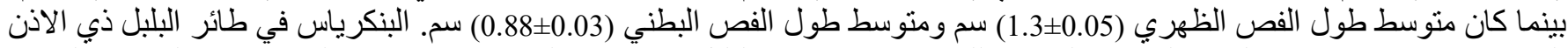



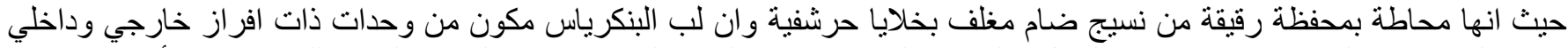

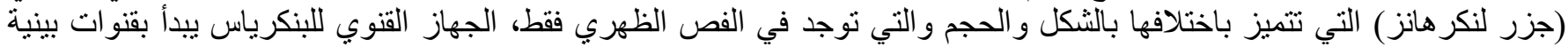

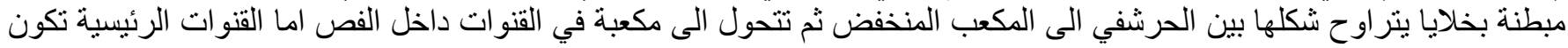




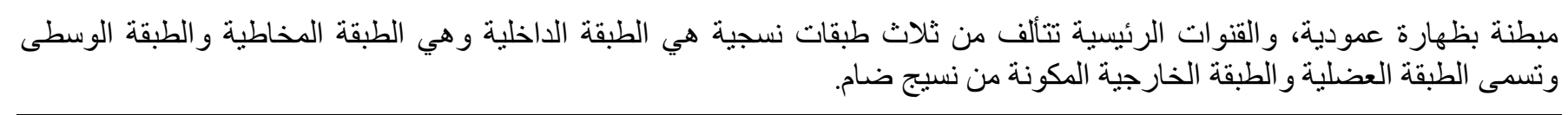

\section{Introduction}

Bulbuls are medium-sized songbirds some are colorful yellow, red or orange vents, there are 130 species worldwide (1), the main accessory organs of digestive system are pancreas and liver $(2,3)$, pancreas in all birds located in right side of the abdominal cavity $(4,5)$.

The number of lobes in avian pancreas are two or more (6) for example in early hatched goose (Anser anser) the number of lobes are four, dorsal, ventral, third and splenic lobe (3) as well as in red jungle fowl (5) record dorsal and ventral as main lobes, small thin lobe called splenic lobe and delicate lobe as subdivision from the ventral lobe called third lobe, or two lobes dorsal and ventral in bustard (7).

In golden eagles (Aquila Chrysaetos) (8) recorded the average body weight and whole pancreas was (1992), 4.073 gm respectively and the average weight of dorsal lobe $2.085 \mathrm{gm}$ while ventral lobe $1.576 \mathrm{gm}$ and the average length of the dorsal and ventral lobes was $4.333,3.588 \mathrm{~cm}$ respectively and the ventral lode is thicker than the dorsal lobe and has a duodenal impression on either sides.

The lobes of pancreas are differs in length, color and shape in birds they were very short, semi-wide pale pinkish to white pinkish and not full the space between the two limbs of duodenum in golden eagles (Aquila Chrysaetos) (8), or ribbon-like pale pinkish and completely fill the space between the duodenal limbs in red jungle fowl (5), the differences in length of pancreas in birds attributed to the type of food so that in duck and goose the pancreas is too short and not reach the end of duodenal limbs $(9,10)$, the shortest pancreas is also found in bustards (7), according to suggestions by (11) in chicken and other birds that feed on grains and seeds, they need more enzymatic activity to compensate for lack their teeth and hydrolytic enzymes in their saliva.

The pancreas was observed by (8) in golden eagle (Aquila Chrysaetos), (12) in goose (Anser Albifrons) and (13) in duck (Ansa platyrhnchos) covered by very thin layer of connective tissue capsule, the capsule sent septa extend to divide the gland into lobules and continues to diffuse between the acinar glands.

The pancreas consist of two portion, endocrine as pancreatic islands which responsible for control of blood sugar (10) and exocrine portion which release many essential electrolytes and digestive enzymes (14), the exocrine portion which observed by (3) in early hatched goose (Anser anser), in duck (Anas boscas) (14) and in the pancreas of the Ostrich (Strohtio camellus) (15) were consist of tubuloacinar glands that occupied larger area from the parenchyma of pancreas. The exocrine part was arranged in form of serous tubuloacinar glands consist mainly of multiple number of acinar cells which take the form pyramidal or tall columnar in shape.

The ductal system of avian pancreas composed of intercalated, intralobular, interlobular duct and main excretory duct (pancreatic ducts), the epithelium which lined the ducts varied from simple cuboidal in intercalated and intralobular duct to tall columnar in interlobular duct, this information was noted by (16) in common Quail (coturnix coturnix), while in early hatched goose (Anser anser) and duck the main excretory ducts were lined by simple to stratified columnar epithelium and these ducts have inner longitudinal and outer circular muscle layers surrounded externally by connective tissue $(3,17)$.

The observations of (5) in pancreas of red jungle fowl appeared that the glandular units showing a polarized cytoplasm with acidophilic zymogenic granules and small centroacinar cells without granules were observed in the lumen of the acini, and the islets of Langerhans were not numerous and were irregular in shape, they were observed frequently in the third lobe, however in the splenic lobe the islets of Langerhans appeared more than other lobes.

Al-Sharoot (3) demonstrate the islands of Langerhans in early hatched goose(Anser anser) consisted of alpha or beta cells, the mixed islets were not observed, while the results of (18) in porcupine (Hystri cristatax) and (19) in houbara bustar (Chlamydotis undulate) the islands of Langerhans containing alpha, beta and delta cells.

The aim of this study to elucidate the morphological and histomophometrical characteristics of pancreas in white eared bulbul.

\section{Materials and methods}

Five healthy adult white reared bulbul were used in our experiment for macroscopic study and the same number for microscopic and histochemical study. All birds were collected from Al-Hilla city markets, they were immediately transferred to the veterinary anatomy laboratory in Al-Qasim green university, the birds were deeply anesthetized by using combination of diazepam (1 $\mathrm{mg} / \mathrm{kg})$ and ketamine HCI $(30 \mathrm{mg} / \mathrm{kg})$ by intra muscular injection route $(20)$, then the chest was opened to make bleeding by puncture the heart to get full hemorrhage and then wash the specimen with tap water to get rid of the impurities, then record the specifications of the pancreas and its relationship with the neighboring organs. Gross examination occur which include the mean weight of birds and pancreas and also length of pancreas. Samples of $1 \mathrm{cc}$ were taken from different lobes of pancreas for histological 
and histochemical study, all specimens were processed by routine histological method to get sections ones of $5 \mu \mathrm{m}$ thickness, the sections was mounted on slides and stained with the haematoxylin and eosin for general structure and P.A.S stains to study the histochemical features of the pancreases (21).

\section{Results}

The anatomical study revealed that the pancreas of withe eared bulbul was a small organ, white in color, located in the right side of the abdominal cavity formed from two lobes ventral and dorsal lobe, the ventral lobe appeared short with navicular shape enclosed by duodenum loops (Fig. 1 and 2) while the dorsal lobe was longer than ventral lobe and very thin like triangular in appearance extend on dorsal surface of ascending limb of duodenum and its base located caudally while the apex extend cranially (Fig. 3 and 4). The two lobes were covered by mesentery and not full occupy the space between the descending and ascending limbs of duodenum. The mean weight of bulbuls was $(27.6 \pm 3.04) \mathrm{gm}$, the mean weight of whole pancreas was $(0.07 \pm 0.022) \mathrm{gm}$, the mean weights of dorsal and ventral lobes was $(0.034 \pm 0.005) \mathrm{gm}$, $(0.036 \pm 0.0054) \mathrm{gm}$ respectively and the mean length of dorsal and ventral lobe $(1.55 \pm 0.02) \mathrm{cm},(0.66 \pm 0.05) \mathrm{cm}$ respectively (Table 1).

Table 1: The mean weight of birds (gm) and the mean weight $(\mathrm{gm})$ and length $(\mathrm{cm})$ of pancreas lobes $(\mathrm{n}=5$, $\mathrm{M} \pm \mathrm{S}$.E)

\begin{tabular}{lc}
\hline Anatomical traits & Mean \pm S.E \\
\hline Birds weight & $27.6 \pm 3.04$ \\
Weight of pancreas & $0.07 \pm 0.022$ \\
Weight of dorsal lobe & $0.034 \pm 0.005$ \\
Weight of ventral lobe & $0.036 \pm 0.0054$ \\
Lenght of dorsal lobe & $1.56 \pm 0.02$ \\
Lenght of ventral lobe & $0.66 \pm 0.05$ \\
\hline
\end{tabular}

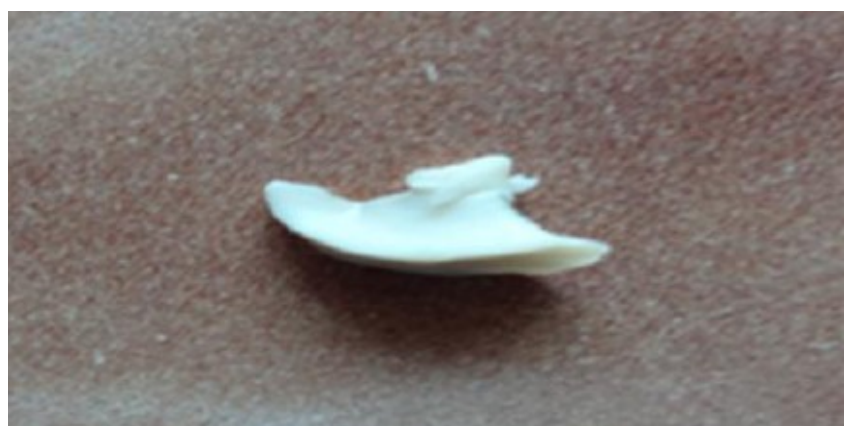

Figure 1: Photograph illustrate. Pancreas of bulbul ventral lobe.

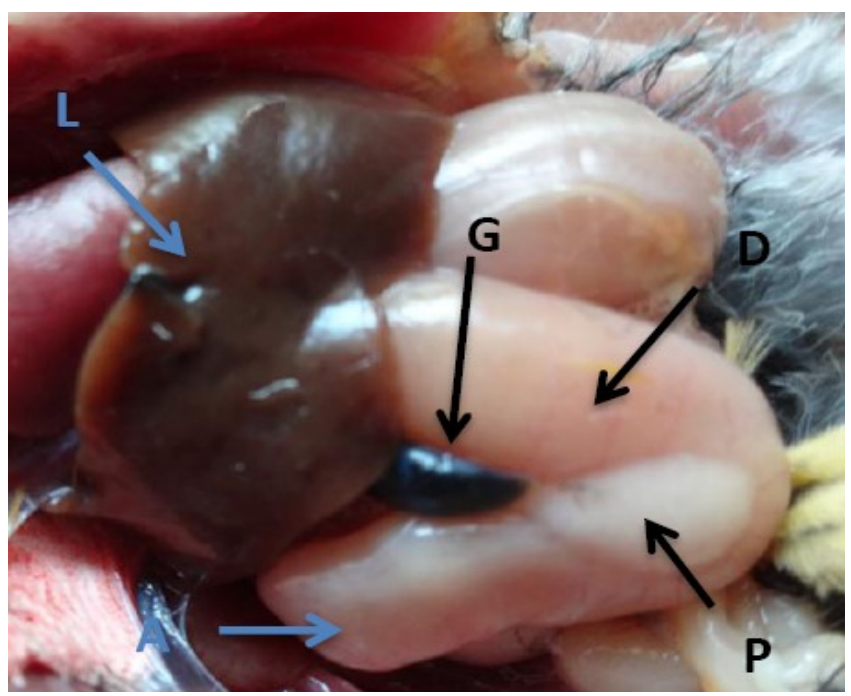

Figure 2: Photograph illustrate, D-descending duodenum Aascending duodenum, P- ventral lobe of pancreas, Ggallbladder, L-liver.

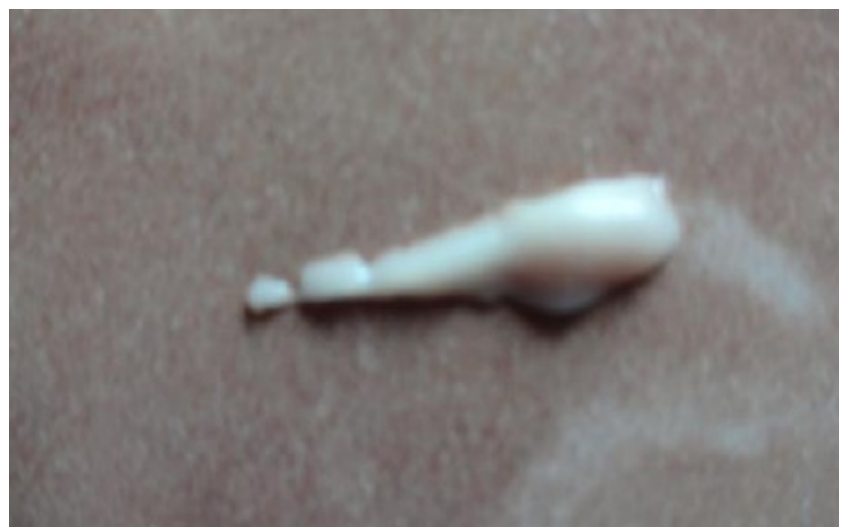

Figure 3: Photograph illustrate. Pancreas of bulbul dorsal lobe.

The pancreas parenchyma of dorsal lobe was consisted of exocrine and endocrine portions (Fig. 5), the exocrine component forms the majority of the pancreas and closely packed of serous tubuloacinar secretory units which made of pyramidal serous cells with granules in the apical part of their cytoplasm, the excretory ducts of the individual acini are visible as pale-staining centroacinar cells, the products leave the acini via intercalated ducts (intralobular ducts) (Fig. 6) which have a small lumen lined by flat to low cuboidal cells, then the products drain into interlobular ducts which located in tissue septa which lined by simple cuboidal cells (Fig. 6). The epithelial cells becomes columnar in larger ducts (main ducts and pancreatic duct) the main excretory ducts composed of three histological layer (Fig. 7), mucosa, muscularis and adventitia layer, the 
mucosa is innermost layer which lined by columnar epithelium with underlining lamina propria (connective tissue) a temporary folds were observed in mucosa layer. Muscularis layer is the second layer was composed of longitudinal smooth muscle fibers as inner layer while the outer layer as circular thick smooth muscle fibers, adventitia a thin connective tissue enclose the muscularis and mucosal layers.

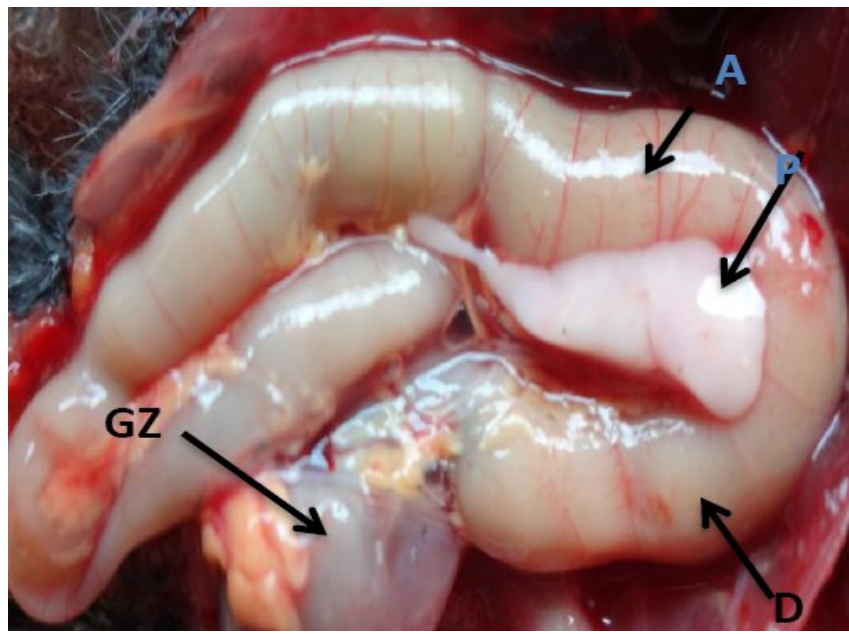

Figure 4: Photograph illustrate, A-ascending duodenum, Ddscending duodenum, P-dorsal lobe of pancreas, GZgizzard.

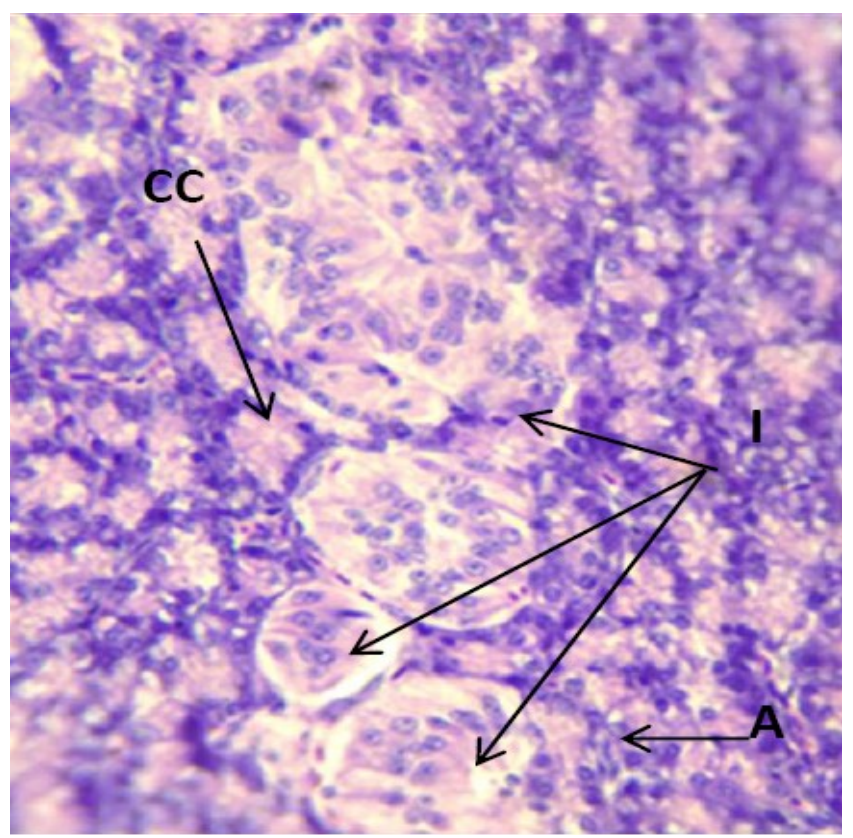

Figure 5: Photomicroscope of pancears (dorsal lobe) illustrate. AC-acinar cells, I-islet of Langerhans, CCcentroacinar cells, (H\&E 20X).

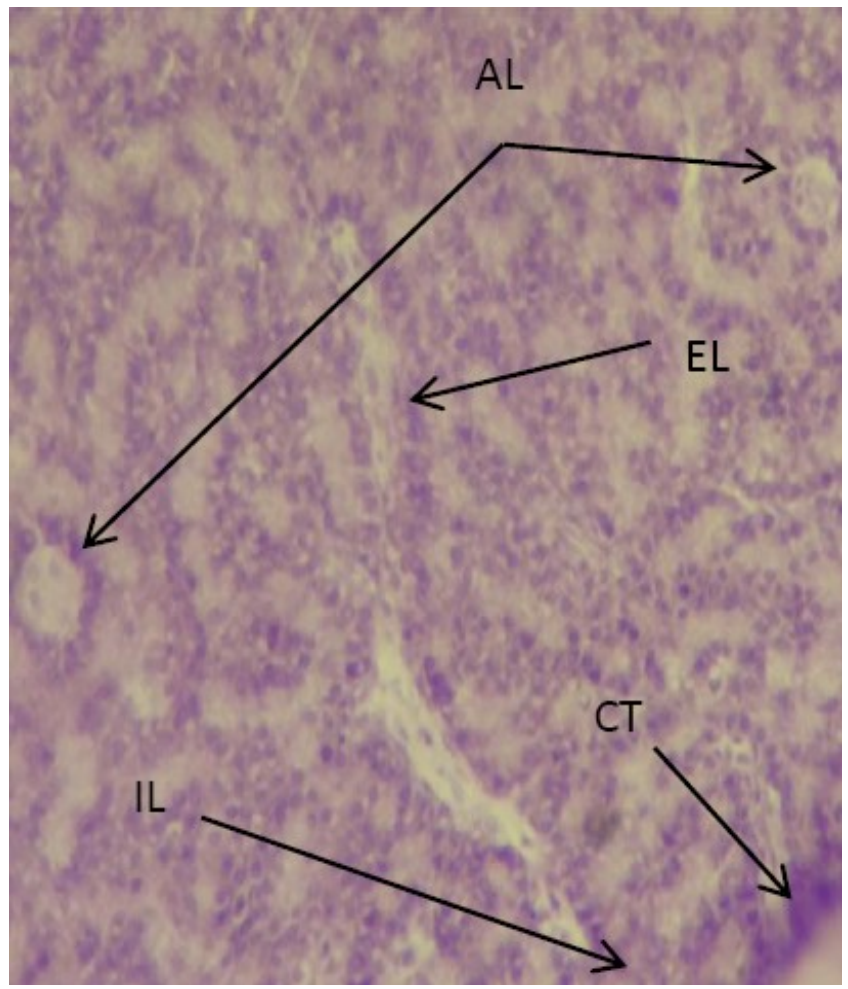

Figure 6: Photomicroscope of pancreas (ventral lobe) illustrate, AL-intralobular ducts, EL-interlobular duct, CTconnective tissue capsule, IL-interlobular septa (P.A.S).

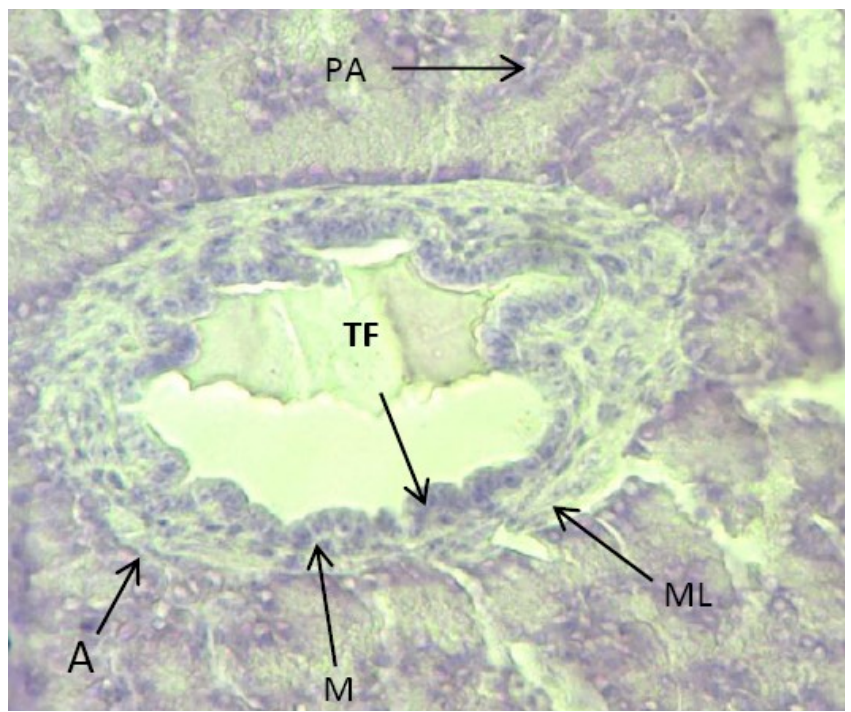

Figure 7: Photomicroscope in pancreatic duct illustrate, TFmucosal fold, M-mucosa, ML-muscularis layer, Aadventitia, PA-pancreatic acini. (P.A.S X20). 
Histologically the pancreas was covered by a thin connective tissue capsule with one layer of mesothelial cells. Connective tissue septa extend from capsule carrying blood vessels, nerves and excretory ducts.

The ventral lobe appeared empty from Langerhans islets in all histological sections (Fig. 6), while the islets appeared in different shapes and sizes in dorsal lobe of pancreas (Fig. 5) which composed of groups of cells without distinctive border with the exocrine portion.

Histochemical results revealed to moderate reactions of periodic acid-Schiff (P.A.S) stain with the apical surfaces of intercalated and interlobular ducts cells while the reaction was strong with cytoplasm of the cells of main pancreatic duct and their secretions (Fig. 6 and 7).

\section{Discussion}

Our study showed that the pancreas of white eared bulbul was located in the right side of the abdominal cavity, this results in concords withe finding of $(4,5)$ whom mentioned the pancreas located in right side of abdominal cavity in birds.

The pancreas of white eared bulbul formed from two lobes ventral and dorsal lobe which correlate to the finding of (7) in bustard,in contrast, our results were disagreement with results of (3) who study the pancreas of early hatched goose (Anser anser), whereas (5) found that the pancreas of red jungle fowl was composed of four lobes.

The two lobes of pancreas in white eared bulbul were appeared as small organs, white in color, the ventral lobe navicular in shape while the dorsal lobe triangular in shape and thinner than the ventral lobe, our results were disagreed with (5) who observed the pancreas in red jungle fowl as pale pinkish and ribbon-like organ also unlike in golden eagle when (8) described the pancreas as pale pinkish to white pinkish in color but our results in agreement with him when noted the pancreas very short and the ventral lobe is thicker than the dorsal lobe.

The dorsal and ventral lobes of pancreas in bulbul not fill the gap between the duodenal limbs, this findings are similar with results of (7) in bustards and (8) in golden eagle while our results disagreement with (5) when talk that the pancreas in red jungle fowl fills the space between the duodenal limbs.

The pancreas appeared as small organs formed from two lobes, the mean weight of whole pancreas was $(0.07 \pm 0.022)$ $\mathrm{gm}$, the mean weights of dorsal and ventral lobes was $(0.034 \pm 0.005) \mathrm{gm},(0.036 \pm 0.0054)$ gm respectively and the mean length of dorsal and ventral lobe $(1.55 \pm 0.02) \mathrm{cm}$, $(0.66 \pm 0.05) \mathrm{cm}$. The pancreas was appeared a small organs in white-eared bulbul because of its dependence on the fruits more than grains on its nutrition that do not require large amounts of enzymatic activity, histologically the pancreas in white-eared bulbul similar to the other birds.
Histologically the pancreas of white eared bulbul was covered by thin capsule with mesothelial cells, from capsule septae extend and divide the gland into lobules our data agreed with (8) in golden eagle, (12) in goose, (13) in duck.

The gland of pancreas in white-eared bulbul composed of two portions, exocrine and endocrine portions. This results come in agreement with (15) in ostrich (Strohtio camellus) and (14) in duck (Anas boscas).

The cells in the lumen of acini were observed simple flattened to low cuboidal cells which represent the starting of intercalated ducts, the interlobular ducts of pancreas in bulbul lined by simple cuboidal epithelia which changed to the columnar in main ducts,our results showed no difference with those of (16) in red common quail (Coturnix coturnix) but differ with him when observed the interlobular ducts lined by simple columnar epithelium,also our results not similar with (17) in duck whom noted the main ducts lined by simple to stratified columnar epithelium.

The endocrine portion of pancreas (islets of Langerhans) appeared in different size as well as irregular in shape and not numerous, our data was agreed with (18) in porcupine (Hustri cristatax) and (19) in houbara bustar (Chlamydotis undulate) but differ with (3) who observed the islets of Langerhans in early hatched goose consist of either alpha or beta islets and the mixed islets do not noticed as well as the islets of alpha cells bigger than beta.

\section{Acknowledgment}

We extend our sincere thanks to the University of AlQasim Green, especially the faculty of veterinary medicine, anatomy branch for its cooperation in accomplishing this research.

\section{References}

1. Clements J F. Birds of the world a Checklist.Cornell University Press,(2000). pp.880.

2. Kim A, Miller K, Kilimnik G, Wojcik P, and Hara M. Islet architecture. A comparative study. Islets, (2009). 1,pp. 129-136.

3. Al sharoot $\mathrm{H}$ A. Anatomical, Histological and Histochemical Architecture of pancreases in Early Hatched Goose (Anser anser). J Vet Med Sci, (2016).7 (1),pp.147-150.

4. Liu JW, Evans H, Larsen P,Pan D, Xu SZ, Dong HC,Deng XB and Wan BG. Gross anatomy of the pancreatic lobes and ducts in six breeds of domestic ducks and six species of wild ducks in china. Anat. Histol. Embryo, (1998). 1. 27, pp. 413-417.

5. Kadhim kk,Zuki ABZ,Noordin MM, Babjee SMA and Zamri-Saad M.Morphological study of pancreatic duct in red jungle fowl African J of Biotechnology Vol,(2010).9 (42), pp. 7209-7215.

6. Gulmez N. Are gland present in Goose pancreatic Ducts? Alight microscope study.Jop.J.pancreas (Online), (2003). 4(3),pp. 125-128.

7. Bailey TA, Mensha BE, Samour J, Naldo J, Lawrence P and Garner A.Comparative morphology of the alimentary tract and its glandular derivatives of captive bustards. J. Anal, (1997). 191: 398. 
8. Al agele RAA and Mohammed FS. Architecture Morphology and Histological Investigations of Pancreas in Golden Eagles (Aquila Chrysaetos).Al-Anbar J. Vet. Sci, (2012). 5 (2).

9. Getty R.Sisson and Grossman S.The Anatomy of the Domestic Animals. Saunders, Vol. 2.5th edn WB Saunders Company, Philadelphia, U.S.A, (1975).pp. 1874-1875.

10. Nickel R, Shummer A and Seiferle E. Anatomy of the domestic birds.Verlag Paul Parey. Berlin. Hamburg. (1977).

11. Gussekloo SWS. Feeding structures in birds, In. V.Bels. (Ed), feeding in domestic vertebrates. from structure to behavior,Wallingford, UK, Combridge.(2006).

12. Mobini B. Histological studies on pancreas of Goose (Anser Albifrons). Vet. Re, (2011). 2 pp.25- 29.

13. Al shaeli SJ. Anatomical and histological study of pancreas in local breed ducks (Anas platyrhnchos, Mallard). M.Sc. Thesis, College of Vet Med.University of Baghdad- Iraq. (2010).

14. Das A, Das RK, and Parida S. Histomorphological study on pancreas of duck (Anas boscas). Indian J. Anim. Sci,(2003). 73 (6), pp.598-599.

15. Gencer BT, Yaman M and Bayrakdar A. Immunohistochemical study on the endocrine cells in the pancreas of the Ostrich (strohtio camellus).J.Anim.Vet. Adu, (2007). (6), pp.693-696.
16. AL-Hathry S A. Topografical,histological and histochemical study of the pancreas of Common Quil (Coturnix C. Coturnix L.). M.Sc.Thesis Univertity of Baghdad -Iraq, (2000). pp.47-48

17. Wang BG, Liang HY and Jie Z. Duck pancreatic acinar cell as a unique model for independent cholinergic stimulation-secretion coupling. Cell Mol. Neurobiol., (2009). (29), pp.747-756.

18. Tarakcy GB, Yaman M,Bayrakdar A and Atlar O. Immunohistochemical detection of Gonadotropin -releasing hormone $(\mathrm{GnRH})$ in porcupine (Hystri cristatax) pancreas. J. Anim.Vet, (2005). (8),pp.741-74 6.

19. Mensah-Brown EPK, Bailey TA,Pallot DJ, Garner A. Pepdidergic hormones and neuropeptides and aminergic neurotransmitters of the pancreatic islets of the Houbara bustar (Chlamydotis undulate). $\mathrm{J}$ Anat. 2004;196:233-241.

20. Schindala MK. Anesthetic effect of ketamine with diazepam in chicken.Iraqi vet.J.Sci, (1999).12,pp.261-265.

21. Kiernan AJ. Theory and practice in histology and histochemical methods.Oxford: Pergamon Press, (2003). pp.35-36. 